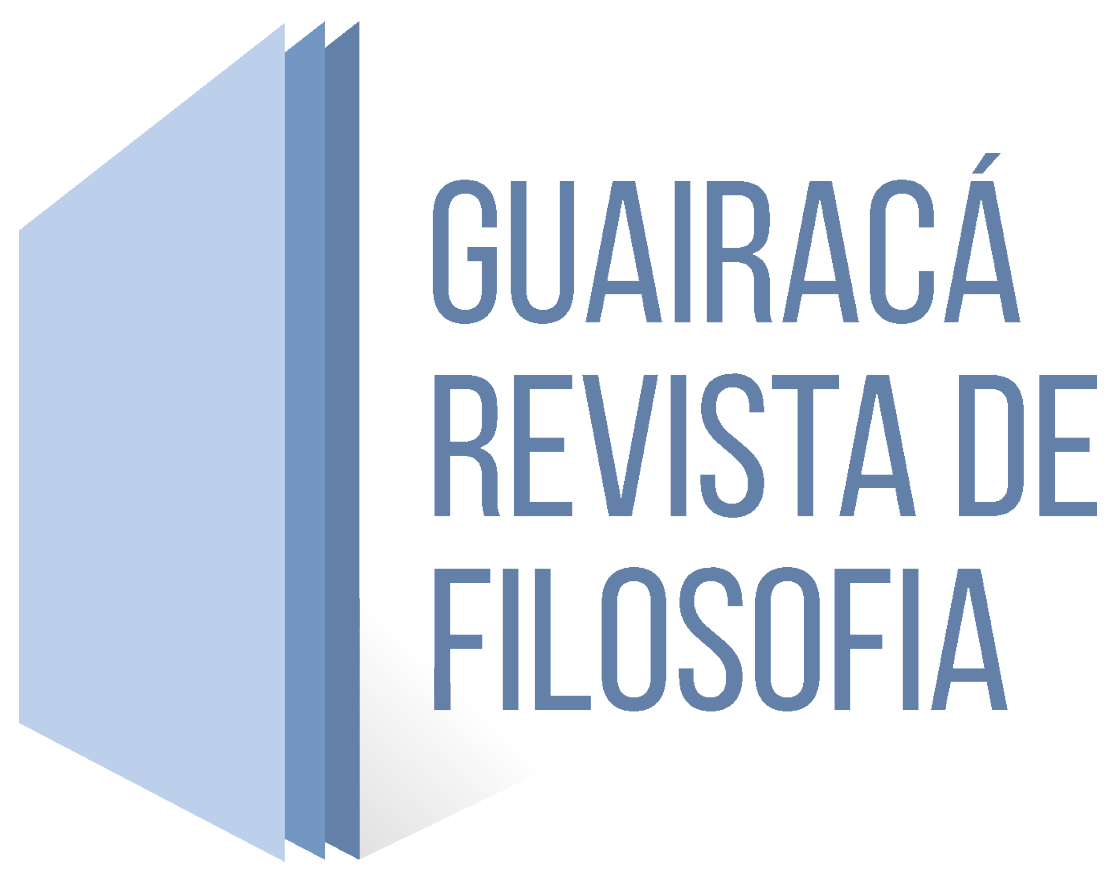

\title{
A BIOTECNOLOGIA E SEUS USOS ENTRE SEMENTES CRIOULAS E TRANSGÊNICAS:DUAS FACES DA TECNOLOGIA E UM CASO PARA A BIOÉTICA'
}
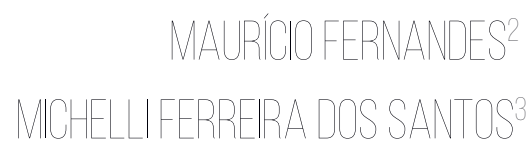

Resumo: Neste artigo, objetiva-se a tematização acerca de usos e formas distintas de tecnologias, e mesmo opostas, presentes no trato em relação às sementes no campo, que envolvem tanto às populações tradicionais (na resistência e luta pela manutenção de sementes crioulas), quanto grandes corporações (que se valem da biotecnologia para a criação de um círculo nefasto que ameaça diretamente a soberania e a existência destas populações campesinas). Evidencia-se assim, formas de tecnologias que transitam em contextos e potenciais diferentes e que representam, metaforicamente, duas faces da tecnologia no contexto do campo. Ressaltamos, a partir de um olhar desde a Filosofia da Tecnologia, que o problema não reside no fenômeno tecnológico em si. A partir da compreensão destas duas formas de tecnologia empregadas no campo, pretende-se tematizar ao debate bioético a gramática dos conflitos no campo enquanto decorrentes dos usos da biotecnologia. As formas de tecnologias aqui descritas são aspectos do próprio fenômeno técnico

1. Este artigo articula-se como um resultado preliminar de uma intervenção interdisciplinar entre Biotecnologia e Filosofia, levada à cabo no interior de um curso de Educação do Campo com habilitação em Ciências da Natureza ofertado pela Universidade Federal do Piauí (UFPI) no campus Senador Helvídio Nunes de Barros (CSHNB). Foi apresentado no XI CONIFIL realizado entre os dias 27 e 31 de maio de 2019 na UNICENTRO em Guarapuava/PR.

2. Universidade Federal do Piauí (UFPI). Email: mauriciofernandes@ufpi.edu.br.

3. Universidade Federal do Piauí (UFPI). Email: michelliferreira@ufpi.edu.br. 
e seu dinamismo no âmbito de nossa trajetória evolutiva. Porém, o elemento de diferenciação é compreendido a partir do prisma do mercado, impresso pela pressão das grandes corporações sobre o desenvolvimento tecnológico e o uso das formas de tecnologia no controle e administração da própria vida e das comunidades do campo. Pretende-se assim, uma contribuição expressa em uma análise da luta silenciosa que se desdobra no campo por décadas e na qual esta implícito tanto o uso de tecnologias quanto o acesso às mesmas de ambos os lados, o que nos lança olhares sobre o próprio fenômeno técnico e seus possíveis usos.

Palavras-Chaves: Filosofia da Tecnologia. Biotecnologia. Sementes Crioulas.

\title{
BIOTECHNOLOGY AND ITS USESBETWEEN CREOLE AND TRANSGENIC SEEDS: TWOFACES OF TECHNOLOGY AND A CASE TOBIOETHICS
}

\begin{abstract}
This paper aims a discussion about distinct and opposite technological forms in the present in the treatment of seeds in the field that involve both traditional populations (in resistance and struggle for the maintenance of creole seeds) and large corporations (which use biotechnology to create a nefarious circle that directly threatens the sovereignty and existence of these peasant populations). In this way, the forms of technology that transpose in different contexts and potentials and that represent, metaphorically, the two faces of technology in the context of the field. We point out, from a view of the Philosophy of Technology that the problem does not lie in the technological phenomenon itself. From a comprehension of these two forms of technology used in field, it is intended to discuss to bioethical debate the grammar of conflicts in the field as results of biotechnological uses. The forms of technologies described here are aspects of the technical phenomenon itself and its dynamism within the scope of our evolutionary trajectory. However, the element of differentiation is understood from the prism of the market, imprinted by the pressure of the big corporations on the technological development and the use of the forms of technology in the control and administration of the own life and the communities of the field. The intention is thus to make an explicit contribution in an analysis of the silent struggle that has unfolded in the field for decades and in which it is implicit both the use of technologies and access to them on both sides, which throws us glances about the phenomenon itself and its possible uses.
\end{abstract}

Keywords: Philosophy of Technology. Biotechnology. Creole Seeds. 


\section{INTRODUÇÃO}

Vivemos uma era marcada pela tecnologia em todas as suas nuances e possibilidades. Desde o final do século XIX a tecnologia emergiu como uma força poderosa impulsionando a ciência e outras estruturas como a economia e a política. A tecnologia ergue-se desde finais do século passado como um verdadeiro Zeitgeist - utilizando aqui uma terminologia de Ferrater Mora, que atinge uma condição basilar nas sociedades e formas de vida contemporâneas.

Desde os estudos de Warren Weaver na década de 1930, até a exposição da estrutura da dupla hélice por Watson e Crick em 1950, e desta, até os primeiros usos da biotécnica conhecida como CRISPR em 2016, a biotecnologia apresentou avanços expressivos e indeléveis em nosso desenvolvimento tecnocientífico; mas também, traz consigo riscos e perigos, e impôs uma série de problemas de ordem nova e urgente envolvendo a vida humana e os usos possíveis da mesma no sentido da experimentação biotécnica.

Desde os alvores de nossa história evolutiva empregamos um processo de seleção de plantas e animais com finalidade na domesticação destas espécies e obtenção de benefícios à espécie humana. Abandonamos o nomadismo, passamos a cultivar o solo criando grandes concentrações humanas em torno da agricultura. Desenvolvemos processos bioquímicos aplicados aos alimentos que ampliaram nosso rol de alimentação e a qualidade dos alimentos.

Neste sentido, possuímos biotecnologia desde aproximadamente seis séculos antes da era comum. A biotecnologia é uma forma de conhecimento e ação humana antiga, porém, atinge contornos polêmicos e alarmantes com seu desenvolvimento nas décadas finais do século $X X$, quando toca em praticamente todos os âmbitos da vida nas sociedades avançadas. Um dos campos tocados pela biotecnologia a partir da segunda metade do século $X X$ foi a busca por resoluções acerca do problema da fome, e mais precisamente, dentro deste eixo, a questão das sementes, seu melhoramento e usos instaurados a partir das grandes corporações.

Segundo a Federação Internacional de Sementes ${ }^{4}$ (ISF) há um crescimento progressivo no mercado de sementes nos últimos anos. Desde a década de 1970 o mercado internacional de sementes experimenta um crescimento exponencial, em grande parte, devido aos avanços recentes no campo das biotecnologias. $\mathrm{O}$ ponto de alerta não reside na biotecnologia em geral, dada a abrangência e profundidade da prática biotecnológica na cadeia evolutiva humana; porém, assim como em outros campos, o perigo reside em uma forma recente da prática biotecnológica (transgenia) aplicada à agricultura e, em especial, às sementes.

4. Disponível em: https://www.worldseed.org/resources/seed-statistics/. 
Desde nossa mais tenra idade como civilização humana, as sementes tornaram-se companheiras em nossa trajetória evolutiva. Foram elemento central no processo de surgimento da agricultura e ainda nos conectam com este passado distante no modo de relação com as sementes e com o solo. As sementes representam um link com fontes simbólicas fundacionais importantes à identidade e consciência de comunidades e povos tradicionais (HEATHERINGTON, 2017). Implicam em um modo mais básico (e também complexo) de relação com a fertilidade da terra, no qual se encontram expressões fenomenológicas, socioculturais e políticas importantes no processo de manutenção e suporte às subjetividades dos povos tradicionais.

O problema aqui abordado reside nos dois modos distintos da biotecnologia envolvendo a manutenção e tratamento de sementes, o que nos fornece elementos para compreendermos o fenômeno tecnológico e seus usos no âmbito do campo. De um lado, a biotecnologia é empregada na manutenção de sementes crioulas (identificação e conservação das sementes, criação de bancos de germoplasma), o que potencializa a luta histórico-social de comunidades tradicionais em suas exigências por autonomia e soberania alimentar. De outro lado, os novos e expressivos avanços no campo das bioengenharias são utilizados amplamente por conglomerados econômicos que avançam progressivamente palmilhando o campo, transformando cada palmo em um pedaço rentável e precificado.

Este trabalho pretende uma reflexão filosófica acerca dos usos e formas biotecnológicas envolvidas na conservação e melhoramento de sementes no campo brasileiro, e os impasses e problemas oriundos de tais usos, constituindo-se como fruto de um esforço inter e transdisciplinar entre Biotecnologia e Filosofia, levado à cabo no interior de um curso de Licenciatura em Educação do Campo com habilitação em Ciências da Natureza em uma IES no semiárido piauiense.

Em acompanhamento às atividades de um grupo de pesquisa acerca da manutenção de sementes crioulas e o resgate da biodiversidade, iniciaram-se debates que transitaram desde a perspectiva hard de melhoramento em seus aspectos biotecnológicos, quanto a problematização de tais técnicas e dos seus impactos no âmbito das comunidades tradicionais.

O trabalho se pretende como uma contribuição à reflexão filosófica e bioética acerca das práticas biotecnológicas no campo do melhoramento de sementes. Pretende-se uma tematização da gramatica conflitual no campo no que diz respeito às sementes, iniciando por uma reflexão sobre as sementes, evidenciando usos e interesses distintos da biotecnologia em relação às sementes. Estes usos e interesses movem entre si a soberania alimentar das comunidades tradicionais, os saberes dos povos do campo, a autonomia, liberdade e a própria sobrevivência de tais; o que nos direciona para uma tematização deste cenário como um caso ao qual ao debate bioético. 


\section{A MANUTENÇÃO DAS SEMENTES CRIOULAS}

\subsection{QUE SÃO SEMENTES CRIOULAS?}

Sementescrioulas ou tradicionais, sãosementesquemantêm suas características genéticas originárias, e são mantidas durante várias gerações em uma determinada comunidade. Estas sementes existem na natureza em grande quantidade, e foram, no decorrer de muitos anos, sendo selecionadas e melhoradas de forma clássica por várias gerações com o intuito de melhor adaptação às necessidades e à realidade das comunidades e dos povos envolvidos em sua manutenção apresentando resistência às intempéries do meio (ALMEIDA \& FREIRE, 2003; SANTOS et al., 2012; TRINDADE, 2006).

Uma das características das sementes crioulas é a riqueza genética que possuem, o que pode assegurar a biodiversidade e redução do processo de erosão genética. Esta riqueza genética permitiu às comunidades campesinas e dos povos tradicionais a manutenção de sua soberania alimentar e variedade de suas culturas através de gerações, passando de pai para filho todo um cabedal de conhecimentos, saberes e práticas acerca do cultivo e manutenção das sementes crioulas.

Hoje, a luta pelo direito de manutenção das sementes crioulas pelos povos e comunidades tradicionais é um processo importante para a manutenção da biodiversidade e de práticas sustentáveis que escapam à lógica predatória do agronegócio e constituem importante impulso de resistência e luta, e da exigência por reconhecimento de tais povos, de sua identidade e também de seus saberes e práticas. As sementes são parte de uma rede de relações estabelecidas pelas comunidades que alimentam uma estrutura simbólica marcada pela luta e também pela esperança, são possibilidades de reconexão com nossa própria natureza e raízes, são estruturas com as quais evoluímos conjuntamente, tanto materialmente quanto simbolicamente. Historicamente impulsionaram nossa espécie em mudanças radicais em nossa constituição e estruturação sócio-histórica e cultural, desde a descoberta da agricultura até as grandes navegações (HANSON, 2015; (HEATHERINGTON, 2017).

Há uma gramática existencial impressa na relação das comunidades tradicionais campesinas no semiárido brasileiro com as sementes que se traduz na nomenclatura com a qual cada comunidade ou região denominam as mesmas. Desta forma, temos as sementes da resistência (Sergipe), as sementes da abundância, sementes da paixão (Paraíba), e as sementes da fartura (semiárido piauiense). 
O que eu quero plantar é o milho jabatão, o feijão corujinha e a fava cara larga, e não a semente que vem de fora. Essas são minhas sementes da paixão. Cada um tem suas sementes da paixão e é nessa diversidade que nós temos que nos apoiar (SILVA \& ALMEIDA, 2007, p. 17).

Uma das ramificações dos conflitos no campo gerados pelo avanço e uso das biotecnologias refere-se aos usos e posse das sementes. De um lado, comunidades tradicionais são dizimadas sob o peso de um turbo capitalismo que avança sobre o campo, e que em sua fase mais cruel intenta arrancar de tais comunidades o direito à manutenção de sua soberania alimentar por parte das regulamentações impostas pelos interesses das grandes corporações. No centro deste impasse a biotecnologia sendo empregada em duas frentes distintas e diametralmente opostas.

\subsection{TECNOLOGIA E CONHECIMENTO TRADICIONAL}

As universidades atualmente, seguindo o debate e posicionamentos de países desenvolvidos interessados na preservação do meio ambiente, investem na promoção de projetos e práticas relacionados com a questão ambiental, com biodiversidade e sustentabilidade. Neste sentido, promovem pesquisas que tragam impactos tanto no campo tecnocientífico quanto socioeconômico e cultural.

Um dos eixos que oferecem potencialidades neste campo são as pesquisas em agroecologia. Assim, a questão referente às sementes crioulas aparece no contexto de uma prática agroecológica com potencialidades múltiplas no contexto da própria existência das comunidades tradicionais. Neste sentido, há um processo promissor de compreensão destes saberes campesinos, tradicionais, e uma troca entre as comunidades e as universidades no intuito da promoção de um saber mais profundo sobre o meio ambiente, as comunidades tradicionais e os sujeitos que as compõem.

Neste âmbito, falo desde uma experiência no interior de um curso oferecido em uma IES no semiárido piauiense no qual um dos grandes eixos da habilitação neste curso é o ensino de ciências. Um dos projetos ${ }^{5}$ que nos chama a atenção é um projeto de resgate da diversidade genética e manutenção das sementes crioulas. A universidade potencializa em seu cerne pesquisas de ponta no intuito de oferecer às comunidades campesinas um reforço em sua gesta na manutenção das sementes (construção de bancos de germoplasma, cursos oferecidos aos (às) guardiões (ãs) de sementes, etc.).

5. O projeto de resgate do patrimônio genético vinculado ao Grupo de Pesquisa em Sementes Crioulas do Semiárido Piauiense (GPESC) cadastrado no Diretório de Grupos de Pesquisa da Capes/CNPq em 2017 e coordenado pela Prof ${ }^{\mathrm{a}}$. Dr ${ }^{\mathrm{a}}$. Michelli Ferreira na UFPI/CSHNB. Um projeto importante que, além de toda a infraestrutura biotecnológica, traz impulsos interdisciplinares ao contemplar em seu cerne uma abertura dialógica à bioética e à agroecologia. 
Embora a universidade produza um ambiente marcado pelo conhecimento tecnocientífico sobre as sementes crioulas, é no contexto das gerações, no interior das comunidades tradicionais, que o conhecimento e a tecnologia estão inscritos primeiramente. Este conhecimento chega à universidade, e esta por sua vez, procura absorver e dar um corpo teórico-científico a este conhecimento e à estas tecnologias primeiras - a do agricultor. E neste sentido, cabe compreender o agricultor, guardião de sementes como um biotecnólogo que possui conhecimentos sobre a seleção, o cultivo e a manutenção das espécies de sementes de sua região.

As primeiras formas de biotecnologia implicadas na manutenção das sementes crioulas referem-se à sua seleção e estocagem (manutenção de sua fertilidade para outras safras). Este tipo de conhecimento é apreendido na tessitura das relações sociais no interior das comunidades, e é passado entre as gerações. Estas primeiras formas implicam seleção, armazenamento, plantio e colheita; e ao final, reinicia-se este ciclo.

Estes conhecimentos e tecnologias são responsáveis pela continuidade das comunidades tradicionais em que estão inseridas. A tecnologia envolve todos os saberes da manutenção das sementes. Há um conceito de tecnologia evidente em cada etapa. Tecnologia como um conjunto de conhecimentos e práticas desenvolvido pelos camponeses na manutenção, reprodução, conservação e distribuição de sementes crioulas.

Existe um rol de processos que envolvem a manutenção de sementes crioulas, e que atualmente recebem estímulos epistêmicos dos meios acadêmicos especializados (universidades), como a criação de bancos de germoplasma, a propiciação de cursos e formação dos guardiões de sementes. Neste sentido, encontram-se perspectivas distintas de tecnologia no contexto de manutenção das sementes. Uma tecnologia arraigada na tradição dos povos e comunidades, que formam uma corrente de saberes e práticas; e outra perspectiva marcada pela especialidade tecnocientífica, pela prática biotecnológica e pela especulação do mercado e da economia.

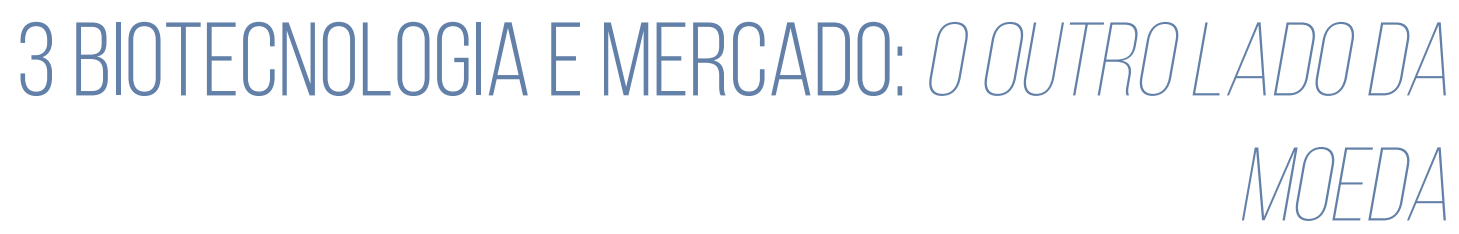

Como um conjunto de práticas e saberes inerentes à atividade humana a Biotecnologia está presente em nossa trajetória evolutiva desde 1700 anos antes da era comum. Processos como a fabricação de cerveja, de queijos dentre outros encontram-se presentes em nosso agir desde tempos muito remotos. Controlamos 
a natureza, e a colocamos para realizar processos que nos beneficiem, isto é o que Hegel chamou de "astúcia da razão".

Logo, enxerga-se que o problema não reside na biotecnologia, ou em algum modo de agir técnico - a técnica em si é um fenômeno que nos caracteriza, e desta forma, os ataques por parte de consciências milenaristas efundamentalistas, daquelas que preveem o fim do mundo, a decadência da espécie humana, só fazem acirrar os ânimos e desfocar o problema. Quando analisamos criticamente a tecnologia, e principalmente, em nossa atualidade, não podemos nos furtar à uma força poderosa a guiar todas as formas da vida contemporânea: o mercado. A tecnologia, assim como outros modos de ação humana no mundo, sucumbe ao mercado, ou antes, passa a ser direcionada por este.

O mercado traga toda a realidade para dentro de si, convertendo tudo em valor econômico, em cifras. Desta forma, o toque do mercado assemelha-se ao do rei Midas. Ele pretende precificar tudo, monetarizar a vida, os fenômenos, o ar, a água. E ao final descobre que o dinheiro não pode comprar o ar puro, ou água cristalina, ou comida saudável. Mas enquanto isto não ocorre, injeta-se toneladas de agrotóxicos na produção do campo, contaminando tudo e todos, potencializa o desmatamento e a exploração sem limites, tendo como horizonte a ilusão de serem inesgotáveis os recursos naturais.

Os discursos acerca dos potenciais biotecnológicos e seus usos na sociedade contemporânea são contraditórios. Vendem a profilaxia de doenças e a supressão da fome (segunda metade do século XX e início do século XXI), mas ainda permanecem na manutenção de patologias (indústrias farmacêuticas) e no acirramento e adoecimento do campo movidos pelo latifúndio.

As grandes corporações fazem uso da biotecnologia não apenas com intuito de se fazer cumprir as promessas inseridas nos discursos midiáticos, como por exemplo a erradicação da fome. Estas empresas utilizam-se da biotecnologia para, na névoa do desconhecimento público e na fragilidade das leis, inserirem no mercado as "sementes da morte". O termo é contraditório, como uma semente pode trazer a morte? Quando ela é esterilizada, tornada infértil. Atualmente há uma tentativa de emprego da tecnologia do gene terminator ou tecnologia do uso de genes restritivos [Gene Use Restriction Technology], que implica na redução da fertilidade da semente em apenas uma safra, o que empurra os pequenos agricultores à um círculo vicioso de dependência da compra de sementes e de insumos (MUKHERJEE; KUMAR, 2014).

As grandes corporações fazem uso da fragilidade das leis para assegurar legalmente o monopólio sobre as sementes, e, por conseguinte, sobre a vida das comunidades. As sementes, compreendidas como artefatos tecnológicos (MARICONDA; RAMOS, 2003), de bem comum passam, gradualmente, à commodities 
sob o mercado de patentes exercido pelas grandes corporações e desta forma, os pequenos agricultores são colocados em um ciclo interminável de dependência frente à tais corporações. Como aponta Barchifontaine e Pessine (1991):

\begin{abstract}
Os agricultores serão obrigados a pagar royalties das prodigiosas sementes pela geração de vegetais e animais que comprem ou reproduzam com fins lucrativos. Os preços das "prodigiosas" sementes patenteadas, conseguidas mediante manipulação genética serão muito mais altos que os das espécies tradicionais, e os agricultores e pecuaristas não poderão, sob pena de ilegalidade renovar suas espécies vegetais e animais sem licenças ou pagamento de royalties. Dessa forma, a comunidade rural perderá seu último mecanismo de controle no primeiro anel da cadeia alimentar e ficará sob a total dependência das companhias transnacionais. (p. 251).
\end{abstract}

A metáfora midiático-mercadológica procura justificar a intervenção cada vez mais profunda de expressões impactantes da alta tecnologia no âmbito da vida humana. Neste sentido, a biotecnologia procura se sustentar sobre discursos terapêuticos no campo das engenharias genéticas sobre o corpo, e sobre expressões imagéticas de abundância e erradicação da fome e da desnutrição, no contexto alimentar. É sobre esta imagem que o discurso biotecnológico procura difundir a produção e o consumo dos transgênicos (que tiveram sua nomenclatura alterada para OGM como forma de driblar o aspecto negativo de sua origem).

Mas afinal, qual o problema relacionado com os transgênicos, se eles são projetados para a eliminação da fome e construção de uma era marcada pela abundância? A questão relativa aos transgênicos, assim, como toda a questão relacionada com os avanços biotecnológicos reside não no fenômeno tecnológico em si, mas em seu atrelamento as forças diretivas do mercado. Se tomamos os avanços no campo das biotecnologias possuímos um corpo material e epistêmico para superar todos estes problemas que assolam a humanidade há séculos.

As patologias podem ser extintas por meio das bioengenharias aplicadas à saúde, ao passo que a fome seria extirpada por meio da bioengenharia aplicada à produção de alimentos. Em ambos os casos há um hiato entre o discurso midiáticomercadológico, que é produzido para atingir o grande público e trabalhar neste sentido a opinião pública, no intuito de normalização dos impulsos de repulsa ainda presentes nesta; e o que realmente se produz, ou o que efetivamente se realiza no campo do avanço biotecnológico, que é mantido sob o controle rigoroso das grandes corporações e conglomerados de acionistas. De forma mais agressiva, as biotecnologias direcionadas pelas forças do mercado rompem com princípios bioéticos, de democracia e cidadania e acirra a desigualdade em decorrência no desequilíbrio do acesso e do usufruto dos benefícios.

O usufruto democrático dos benefícios decorrentes do desenvolvimento científico e tecnológico, portanto, está muito longe de ser alcançado. Esta é uma dura e crua 
realidade: quem tem poder de compra vive mais, quem é pobre vive menos. E a vida, em muitas instâncias, passa a ser um negócio: rentável para alguns, principalmente para os proprietários de companhias internacionais seguradoras de saúde; e inalcançável para uma multidão de excluídos sociais que não têm condições de acesso às novas descobertas e seus benefícios decorrentes (GARRAFA, 2000, p. 15).

O problema é que estes conglomerados procuram, alinhados com a força de um turbocapitalismo extremamente predatório, expandir seu controle sobre o campo, e neste sentido, avançam vorazmente sobre comunidades e povos, financeirizando cada palmo de terra, sufocando a produção e a soberania destes povos, condenando-os à ruina. A lógica mais cruel imposta pelo mercado sobre os camponeses e que mostra a amplitude das forças diretivas do mercado sobre os laboratórios está expressa na esterilização das sementes. A semente perde sua conexão com a vida, com os ciclos de fecundidade.

Desta forma, criou-se, principalmente em países do terceiro mundo uma luta dos povos do campo por sua sobrevivência e para fugirem desta imposição das indústrias que procuram monopolizar as sementes. Esta prática é totalmente oposta ao discurso midiático-mercadológico. Como se cria abundância esterilizando as sementes? Qual a lógica que subjaz à esta prática das grandes corporações? A única lógica para tal, reside no fato destas grandes corporações terem interesses estritamente particulares de ampliação do poderio econômico e do controle do campo, a expansão do latifúndio. Assim, este discurso maquia o rastro de destruição causado por estes conglomerados. $\mathrm{O}$ uso da biotecnologia nestes dois contextos está marcado por sua aproximação com a vida em uma forma, e na outra com as forças do mercado.

O que diferencia estas duas formas de tecnologia é o nível de interação com o mercado, com o agrobusiness. Uma primeira forma está vinculada à um processo de transmissão de saberes enraizado no seio de uma comunidade, na qual os sujeitos participam ativamente tendo esta forma de tecnologia como tática de vida, como um veículo através do qual a comunidade se mantém viva, incluindo todo o corpo de tradições e narrativas culturais que envolvem o próprio processo de manutenção das sementes.

Do ponto de vista do território camponês, o conhecimento tradicional é fundamental para a conservação genética, a diversidade biológica e a reprodução de formas de manejo tradicional, onde as sementes das variedades locais se misturam e se trocam permanentemente; por outro lado, para o território das transnacionais, todas as sementes devem ser padronizadas em sistemas de produção e propriedade que permitam a fácil circulação dos canais de comercialização e apropriação das mesmas (GRAJALES, 2010, p. 06). 
Porém, esta primeira forma de tecnologia é confrontada por outro tipo de tecnologia que, diametralmente oposta, se posiciona no campo do agrobusiness, no âmbito das grandes corporações que possuem no campo o meio para sua ampliação e controle sobre todas as formas de tecnologia que envolvam o alimento. Neste sentido, a produção do campo é mera mercadoria, objeto de especulação e domínio. Dentro da agenda extensa do agrobusiness há uma específica que se relaciona com o comércio de sementes, e, por conseguinte com o mercado de transgênicos. Esta agenda específica faz uso de um dos conjuntos mais expressivos em biotecnologia no intuito de expandir as fronteiras do agronegócio.

Com a expansão do poderio das grandes corporações sobre as sementes reduz-se drasticamente a biodiversidade, ocasionando uma erosão genética. Dos milhares de espécies cultivadas pelos povos tradicionais, há uma imposição da indústria no consumo de basicamente quatro espécies transgênicas - o milho, a soja, a canola e o algodão.

A biotecnologia associada ao melhoramento de sementes por parte da agroindústria oferece em finais do século $\mathrm{XX}$ duas formas nefastas e perigosas. A primeira conhecida como gene terminator ou sementes não germinativas. Esta tecnologia foi desenvolvida e patenteada em 1998 por Delta and Pine Land, que pertencia à Monsanto que a desenvolveu em parceria com o departamento da Agricultura dos EUA, e demais empresas como BASF, Syngenta, Du Pont. A segunda refere-se à tecnologia traitor $^{6}$ ou semente traidora - desenvolvida pela universidade de Perdue (EUA) na qual a semente é não germinativa, mas pode tornar-se germinativa com o uso de produtos químicos nas lavouras. Esta ficou conhecida como semente Lázaro, por sua possibilidade de ressurreição.

\section{UM CASO PARA A BIOÉTICA}

Um dos eixos aporéticos aos quais se volta a bioética hodiernamente, face aos avanços biotecnológicos, é referente aos transgênicos. Tais produtos da moderna biotecnologia impactaram o modo de vida das populações sob o discurso da erradicação da fome, porém, hoje, compreende-se que geraram mais problemas que soluções. Como aponta Paolo Fontana (2013):

Parecem ter sido dissipadas as dúvidas sobre a sua periculosidade para a saúde e para o ambiente (sob condições específicas), enquanto - ao contrário das

6. Cf. ETC GROUP. Traitor Technology: How Suicide Seeds Work/Where they are been Patented, 1999. Disponível em: https://www.etcgroup.org/content/traitortechnology-how-suicide-seeds-work-where-they-are-being-patented. Acesso em: 29/08/2019. 
promessas - eles não resolveram a chaga da desnutrição. A única certeza é que as plantas geneticamente modificadas são fonte de enormes negócios para poucas multinacionais e de grandes problemas para os pequenos agricultores.

A Bioética possui uma variabilidade muito grande em sua conceituação e também em seus âmbitos de debate. As discussões no hemisfério norte giram em torno de "avançadas situações-limite decorrentes do desenvolvimento científico e tecnológico", o que não pode ser aceito acriticamente pelo hemisfério sul onde os problemas ainda se detêm sob um prisma forte da luta política, da luta contra a pobreza e o subdesenvolvimento, contra ecos da colonização, da luta contra o latifúndio e um turbocapitalismo desenfreado que coloca em risco o meio ambiente e populações tradicionais.

A questão das sementes crioulas nos apresenta uma perspectiva que se abre como um caso para acesso da bioética à gramática dos conflitos no hemisfério sul, a estes outros pontos submersos. A bioética descobrirá ser a questão dos transgênicos apenas a ponta do iceberg de tal gramática. E que sob o discurso movido pela ideia de progresso e desenvolvimento do campo ocorre, ao contrário, monopólio e concentração de renda, expansão do latifúndio e avanço do agronegócio sobre o campo, ou seja, antes da questão dos transgênicos (de seu uso ou não) há a questão da luta política por sobrevivência das comunidades e manutenção de sua autonomia.

\begin{abstract}
A discussãobioética surge, assim, para contribuir na procura de respostas equilibradas ante os conflitos atuais e os das próximas décadas. Já tendo sido sepultado o mito da neutralidade da ciência, a bioética requer abordagens pluralistas baseadas na complexidade dos fatos. Para os países do Hemisfério Sul, no entanto, não é suficiente a aceitação acrítica, tampouco as amarras (ou limitações) conceituais sobre bioética, vindas dos países do Primeiro Mundo, onde as discussões giram preferencialmente em torno de avançadas situações-limite decorrentes do desenvolvimento científico e tecnológico. Os estudiosos do assunto têm o compromisso de aproveitar a abrangência e oportunidade que a bioética proporciona, em se tratando de um movimento (ou uma nova disciplina, se os leitores preferirem...) que estuda a ética das mais diferentes situações de vida, ampliando seu campo de influência teórica e prática do exclusivo âmbito biomédico/biotecnológico até o campo ambiental, passando, inequivocamente, pelo campo da bioética social (GARRAFA, 2005, pp. 131-132).
\end{abstract}

Apontamos que o impasse e ambiguidade dos usos das biotecnologias no campo seja tematizado como um caso para a bioética, e de vital importância dada sua profundidade e impacto na existência das comunidades e povos tradicionais que são destituídos de seus direitos via regulamentações impostas pelas grandes corporações.

Uma rápida e básica exposição, se posicionarmos as sementes crioulas e as transgênicas frente aos conteúdos clássicos da bioética principialista (autonomia, 
justiça, beneficência e não maleficência) poderemos visualizar a nocividade das práticas das grandes corporações, ao mesmo passo em que podemos apontar para os potenciais latentes no contexto da manutenção das sementes crioulas. O quadro abaixo nos fornece uma visão não exaustiva destas potencialidades e riscos inerentes a estas duas formas de trato com as sementes:

\begin{tabular}{|c|c|}
\hline Sementes Crioulas & Sementes Transgênicas \\
\hline $\begin{array}{lll}\text { Promovem a soberania alimentar, } \\
\text { asseguram a biodiversidade, a } \\
\text { participação das comunidades nas } \\
\text { decisões sobre as sementes. }\end{array}$ & $\begin{array}{l}\text { Retira a autonomia dos pequenos } \\
\text { agricultores diante de um monopólio } \\
\text { das sementes. }\end{array}$ \\
\hline $\begin{array}{l}\text { Ampliam as práticas agroecológicas, a } \\
\text { produção de orgânicos, o abandono do } \\
\text { uso de insumos químicos. }\end{array}$ & $\begin{array}{l}\text { Impulsionam a monocultura acirrando } \\
\text { o processo de erosão genética e } \\
\text { empobrecimento do solo e de uso de } \\
\text { agrotóxicos. }\end{array}$ \\
\hline $\begin{array}{l}\text { Promovem a participação da comunidade } \\
\text { no processo de seleção, guarda e } \\
\text { distribuição das sementes. }\end{array}$ & $\begin{array}{l}\text { Impossibilitam a transferência } \\
\text { tecnológica e promovem a criação } \\
\text { de um monopólio das sementes via a } \\
\text { cultura de patentes. }\end{array}$ \\
\hline
\end{tabular}

Quadro 01 - Diferenciações entre sementes crioulas e transgênicas. Fonte: Autor.

A luta pela manutenção das sementes crioulas responde, de um lado, uma exigência ética frente ao avanço desenfreado de um turbocapitalismo sobre o campo brasileiro, e de outro à sentimentos premonitórios de uma possível extinção da vida, o que corrobora a construção de grandes centros de manutenção do maior número de sementes possível. A luta pela manutenção das sementes crioulas é uma luta pela manutenção do direito da fertilidade natural, a mesma fertilidade que mantém as comunidades e lhes alimenta, não apenas materialmente, mas também, simbolicamente. É uma luta pela conservação de um corpo de saberes tradicionais que alimentam a soberania e autonomia das comunidades.

Um posicionamento mais cauteloso nos levaria a reconhecer que devemos corrigirprimeiroasgrandesmazelasquemarcamnossasociedadeantes deapostarmos todas as fichas em respostas prontas e "perfeitas" de aplicação biotecnológica às cegas; pois, por debaixo da névoa do desconhecimento da esfera pública transitam interesses muito claros de controle e administração da vida humana e não humana no sentido de manter o poder econômico das grandes corporações.

$\mathrm{O}$ que procuramos expor aqui no âmbito das sementes aproxima-se do exposto por Ivan Illich em $A$ Expropriação da Saúde ${ }^{7}$, na qual aponta que por detrás do discurso terapêutico ocorre uma iatrogênese, na qual o que menos importa é a saúde,

7. Cf. ILLICH, Ivan. A Expropriação da Saúde: Nêmesis da Medicina. 3 ed. Rio de Janeiro: Nova Fronteira, 1975. 
mas sim a manutenção da doença. Neste sentido podemos falar da existência de um conflito já não mais subterrâneo e silencioso, que representa não apenas a morte da semente, com a retirada de seu potencial de fecundidade, quanto das comunidades que dependem desta fecundidade.

Diante desta realidade, quais as possibilidades de saída ou de resolução a este conflito? Primeiramente, esclarecemos que não se trata aqui de uma crítica infundada à biotecnologia, nem mesmo de posicionamento de todo o corpo problemático nos domínios da mesma. A biotecnologia apresenta ganhos indeléveis e nos oferece possibilidades poderosas e reais de ação sobre problemas que nos acompanham a milhares de ano. E desta forma, assim como todo o aparato tecnocientífico, não há uma possível abordagem deontológica a estes problemas, sem a exposição de desconhecimento das estruturas normativas atuais em relação aos avanços ocorridos na biotecnologia. Ainda estamos nos aproximando, porém, a cada passo, a biotecnologia imprime outro passo largo à nossa frente.

Assim, enquanto estamos nos aproximando das possibilidades tornadas reais como a clonagem e mapeamento do genoma humano e seus impactos no início do século XXI, laboratórios chineses realizaram, entre 2016 e 2018, 87 intervenções envolvendo a técnica CRISPR cas9. Neste sentido, quais as perspectivas que nos estão reservadas?

Algo que visualizamos como possibilidade frente a este quadro se articula no campo de uma Antropologia Normativa, que possa buscar instaurar uma retomada da responsabilidade e da cautela frente aos usos das biotecnologias. Diante da perda de referenciais normativos parece-nos possível uma antropologia normativa e pluralista, que possa estimular a retomada de reflexões sobre o quadro drástico que se abate sobre o meio ambiente e que é acirrado por um direcionamento das biotecnologias marcado por interesses de grupos pequenos.

Tal perspectiva se relacionaria, no interior de uma bioética intervencionista, no sentido de fomentar o debate e as intervenções nas comunidades buscando assegurar as condições para sua reprodução simbólica (mediante ao reforço das estruturas tradicionais dessaberes, práticas e conhecimentos) e também de sua reprodução material (promovendo estímulos à transferência tecnológica, capacitação das comunidades, rede de troca epistêmica com as universidades).

\section{CONSIDERACGÕES FINAIS}

Como apontamos, este texto trata de resultados preliminares de uma intervenção interdisciplinar entre a Biotecnologia e a Filosofia no tocante à manutenção das sementes crioulas em uma IES no semiárido piauiense. Procuramos 
apresentar um cenário não exaustivo acerca da realidade referente às sementes crioulas e da luta das comunidades para sua própria sobrevivência frente ao avanço do agronegócio - que impõe outro tipo de uso da biotecnologia sobre o campo e as populações tradicionais.

Como um resultado preliminar podemos reforçar a compreensão de ser a luta pelas sementes um posicionamento ético frente à vida, e garantias de reprodução desta, que oferecem às comunidades estímulos e esperanças. $O$ projeto ainda tem duração de quatro anos pretende trabalhar mais profundamente, no campo institucional, elementos importantes e inerentes às possibilidades presentes na prática biotecnológica, e também plástico-simbólicas das comunidades.

As universidades se abrem a troca epistêmica, porém, mantém uma estrutura que ainda alimenta o agronegócio, o que caracteriza a ambiguidade dos usos da biotecnologia. Porém, longe de ser uma crítica contundente e depreciativa das biotecnologias, o que verifica-se no campo brasileiro é a desigualdade social que é resultado direto da falta de políticas públicas que fomentem a transferência tecnológica, dotando de condições materiais as comunidades tradicionais.

Como possibilidade diante do cenário conflituoso procuramos evidenciar uma alternativa inicial ancorada numa Antropologia Normativa. Na possibilidade de retomada da responsabilidade e que, mediante à luta política, pudesse imprimir um arrefecimento do avanço da lógica predatória do mercado sobre o campo. Uma possibilidade responsável que podemos apontar de forma preliminar no trato das comunidades com as sementes, no conhecimento e aplicação das tecnologias disponíveis na manutenção das sementes crioulas. Esta Antropologia Normativa é apenas uma possibilidade inicial, uma possível alternativa, num âmbito no qual outras contribuições são bem-vindas.

Progressos estão ocorrendo quando as comunidades tradicionais se unem. Há uma voz que ecoa no deserto midiático atual, e essa voz contradiz o discurso do agro ser pop e ser tech, essa voz traz inscrita em si um conjunto milenar de trato com o meio ambiente, com o planeta. Hoje, mediante a luta política, esta voz começa a ser ouvida com mais força, e em sua fala traz a resistência, mas também esperança!

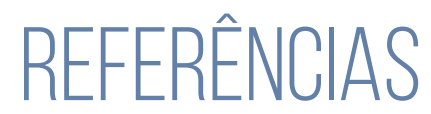

ALMEIDA, P.; FREIRE, A. Conservando as sementes da paixão: duas histórias de vida, duas sementes para a agricultura sustentável na Paraíba. In: Sementes, patrimônio dos povos a serviço da humanidade. H.M Carvalho (org). São Paulo: Ed.Expressão popular. p. 279-302. 2003. 
BARCHIFONTAINE, C. P., PESSINEE L. Problemas atuais de Bioética. 3 ed. São Paulo: Loyola \& Faculdades Integradas São Camilo. 1991.

FONTANA, Paolo. Ogm e Fame, La Rivoluzzione Mancata. In: Popoli, № 2, Febbraio 2013. Disponível em: http://www.popoli.info/easyne2/Articolo/Ogm_e_fame_la_ rivoluzione_mancata-6077.aspx. Acesso em: 05/04/2019, pp. 14-16.

GARRAFA, Volnei; COSTA, Sérgio Ibiapina (Orgs.). A Bioética no Século XXI. Brasília: Editora Universidade de Brasília, 2000.

GRAJALES, Gloria Inés Cárdenas. El conocimiento tradicional y el concepto de territorio. NERA - Núcleo de Estudos, Pesquisas e Projetos de Reforma Agrária - Artigo do mês: fevereiro de 2010. Disponível em: http://docs.fct.unesp.br/nera/ artigodomes/2artigodomes_2010.pdf. Acesso: 29/08/2019.

HANSON, Thor. The triumph of seeds: how grains, nuts, kernels, pulses, and pips, conquered the plant kingdom and shaped human history. New York: Basic Books, 2015.

HEATHERINGTON, Tracey. Seeds. Theorizing the Contemporary. Cultural Anthropology Journal, June 28, 2017 < https://culanth.org/fieldsights/1161-seeds>. Acessado em 30/03/2018.

MARICONDA, Pablo \& RAMOS, Maurício. Transgênicos e ética: a ameaça à imparcialidade científica. In: Scientiae Studia, 1(2), 2003, pp. 245-261. Disponível em: http://www.revistas.usp.br/ss/article/view/10975. Acesso em: 29/04/2019.

MUKHERJEE, Subhajit; KUMAR, Nachimuthu Senthil. Terminator gene technology - their mechanism and consequences. In: Science Vision. Vol 14 Issue No 1 JanuaryMarch 2014. Disponível em: http://oaji.net/articles/2014/1315-1412773499.pdf. Acesso em: 29/05/2019.

SANTOS, A. S.; SILVA, E. D.; MARINI, F. S.; SILVA, M. J. R.; FRANCISCO, P. S.; VIEIRA, T. T.; CURADO, F. F. Rede de bancos de sementes comunitários como estratégia para conservação da agrobiodiversidade no Estado da Paraíba. In: II Congresso Brasileiro de Recursos Genéticos, 2012. Anais. Belém, PA. 2012.

TRINDADE, C, C. Sementes crioulas e transgênicos, uma reflexão sobre sua relação com as comunidades tradicionais. Universidade do Estado do Amazonas. 2006. Disponível em: http://www.conpedi.org.br/manaus/arquivos/anais/manaus/ estado_dir_povos_carina_carreira_trindade.pdf. Acesso em maio de 2019. 